\title{
Norepinephrine infusion increases urine output in children under sedative and analgesic infusion
}

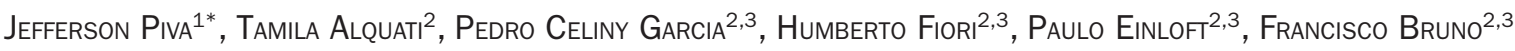 \\ ${ }^{1}$ Full Professor of Pediatrics - UFRGS University (Brazil). Medical director of the Pediatric Emergency and Intensive Care Department - Hospital de Clínicas de Porto Alegre, Porto Alegre, RS, Brazil \\ ${ }^{2}$ Pediatric Intensive Care Unit H. São Lucas - PUCRS University, Porto Alegre, RS, Brazil \\ ${ }^{3}$ Associate Professor of Pediatrics. PUCRS University, Porto Alegre, RS, Brazil
}

Study conducted at Hospital de Clínicas de Porto Alegre, Porto Alegre, RS, Brazil

Article received: 01/18/13 Accepted for publication: 01/09/14

*Correspondence: Adress: Rua Vicente da Fontoura, 3008 - apto. 301

Porto Alegre, RS - Brazil

ZIP Code: $90.640-002$ Fax: +55 513332.0089

jpiva@terra.com.br

http://dx.doi.org/10.1590/1806-9282.60.03.008

Conflict of interest: none

\section{SUMmarY}

Objective: to evaluate the effects of early norepinephrine (NE) infusion in children submitted to mechanical ventilation (MV) requiring continuous sedative and analgesic infusion.

Methods: double-blinded, randomized, placebo-controlled trial enrolling children (1 month to 12 years of age) admitted to a Brazilian PICU and expected to require $\mathrm{MV}$ and continuous sedative and analgesic drug infusions for at least five days. Children were randomized to receive either norepinephrine (NE) $(0.15 \mathrm{mcg} / \mathrm{kg} / \mathrm{min})$ or normal saline infusion, started in the first 24 hours of MV, and maintained for 72 hours. We compared hemodynamic variables, fluid intake, renal function and urine output between groups.

Results: forty children were equally allocated to the NE or placebo groups, with no differences in baseline characteristics, laboratorial findings, PRISM II score, length of MV, or mortality between groups. The average norepinephrine infusion was $0.143 \mathrm{mcg} / \mathrm{kg} / \mathrm{min}$. The NE group showed higher urine output $(p=0.016)$ and continuous increment in the mean arterial pressure compared to the baseline $(\mathrm{p}=0.043)$. There were no differences in the remaining hemodynamic variables, fluid requirements, or furosemide administration.

Conclusion: early norepinephrine infusion in children submitted to MV improves mean arterial pressure and increases urine output. These effects were attributed to reversion of vasoplegia induced by the sedative and analgesic drugs.

Key words: vasopressor; vasoplegia; shock; sedation; urine output.

\section{INTRODUCTION}

Most children undergoing mechanical ventilation (MV) require administration of analgesic and sedative agents to optimize comfort and safety, facilitate patient-ventilator synchrony, and optimize oxygenation. Inadequate sedation can lead to accidental/unplanned removal of invasive devices, ventilator asynchrony, increased oxygen consumption, or unpleasant memories. ${ }^{1-5}$ In recent decades it has been demonstrated that adults and children submitted to prolonged MV support receive progressively higher amounts of sedative and analgesic drug infusion, and some are excessively sedated. ${ }^{1-5}$ Over-sedation is associated with increased duration of $\mathrm{MV}$ and longer intensive care unit stay. ${ }^{2,3,5,6}$
Intravenous (IV) opioids (morphine or fentanyl) and benzodiazepines (midazolam) are the preferred sedative and analgesic association used to sedate children submitted to MV. ${ }^{3,4,5}$ Prolonged sedative and analgesic infusions frequently induce paralytic ileum, arterial blood hypotension, cardiac dysfunction (i.e., bradycardia and decreased contractility), as well as withdrawal or delirium syndromes. ${ }^{1-7}$ The current guidelines for sedation of children submitted to MV aim to avoid over-sedation, maintaining alertness and child interactivity. ${ }^{4-5}$

Hypotension is common to all sedative and analgesic drugs and it is attributed to decreased environmental stimulation (sedation), decreased sympathetic tone (vasople- 
gia), and induced vasodilatation. ${ }^{1,2,5,7}$ These effects are present even with low doses to maintain superficial sedation. ${ }^{4,7}$ Patients in which the primary disease compromises one of the components of the cardiovascular system (i.e., blood volume, cardiac pump, or peripheral vascular resistance), sedative and analgesic drugs can worsen tissue perfusion. ${ }^{1,2,4,5,7}$

Critically ill children with circulatory instability and/ or hypotension have high susceptibility to develop renal damage. Therefore, maintaining adequate renal perfusion-pressure is crucial to preserve the renal function. ${ }^{8,9}$ In this regard, use of an early vasopressor infusion (e.g., norepinephrine) in children receiving sedative and analgesic infusions could reverse the systemic and renal effects of vasoplegia that is induced by these drugs. The improvement in systemic circulation would impact on clinical and laboratorial parameters, such as urine output, creatinine serum levels, blood lactate, free water deficit, and excreted sodium fraction. ${ }^{10-12}$

Despite norepinephrine being recommended in the treatment of pediatric septic shock, there are scarce studies evaluating the effects of this vasoactive drug in children., ${ }^{8,913}$ The aim of this pilot study was to evaluate the hemodynamic response and the impact on urine output of an early norepinephrine infusion in a group of children submitted to $\mathrm{MV}$, receiving usual doses of IV sedative and analgesic drug infusions (morphine/fentanyl plus midazolam).

\section{Methods}

Between November 2009 and November 2010 we conducted this randomized double-blinded, placebo-controlled pilot study, enrolling all mechanically ventilated children requiring sedative and analgesic infusions in a regional Pediatric Intensive Care Unit (PICU) in Brazil. This nine bed PICU is located in the General Hospital of Caxias do Sul (Southern Brazil). This university-affiliated hospital is a regional reference for adults and children with medical and surgical critical illnesses, and also has a Pediatric Intensive Care fellowship program. The study was registered in the clinicaltrials.gov (NCT 00894621) and was approved by the local Ethics and Research Committee.

Children aged 1 month to 12 years, admitted to the PICU during the study period, submitted to MV in which sedative and analgesic infusions would be required for at least 5 days were eligible for the study. Written consent was obtained from parents or guardians after they received all the information about the study protocol. Children with tracheotomy, presenting with hepatic, renal or thyroid diseases, pheocromocytoma, cardiac arrhythmia, or after cardiopulmonary reanimation were excluded from the study.
During the first 24 hours of MV, children included in the study were allocated to receive (in addition to their treatment) one of the following infusions:

- NE-group: norepinephrine continuous infusion $(0.15 \mathrm{mcg} / \mathrm{kg} / \mathrm{min}$ at a rate of $1.5 \mathrm{~mL} / \mathrm{h})$;

- placebo-group: normal saline infusion (at a rate of $1.5 \mathrm{~mL} / \mathrm{h})$.

Patients were randomized in blocks of ten (five cases in each group), using sealed and opaque envelopes referring the solution to be infused. The solution was prepared in the hospital pharmacy being the medical and the nurse staff blinded to its content. The solution was instituted independently of the use of additional vasoactive drug infusions (including, norepinephrine) or catecholamine sparing agents (e.g. hydrocortisone or vasopressin) started before the initiation of study.

The allocated solution should be stopped after the $72^{\text {nd }}$ hour. The attending physician, in case of concerns attributed to infusion solution, was allowed to discontinue the study at any moment. This withdrawal of the study was considered a failure and the reason for cessation should be reported.

On the other hand, if the patient did not complete the period of infusion, (72 hours) due to tracheal extubation (and interruption of sedation infusion), the patient was analyzed in an intention to treat fashion.

General demographic characteristics, the main clinical condition leading to the need for MV, as well as vital signals at the moment of inclusion in the study were recorded. Severity of illnesses was estimated using the Pediatric Risk of Mortality (PRISM II) score. After the intervention period (72 hours), children were followed up to the PICU and hospital discharge.

During the 72 hours of study, the following variables were recorded:

- systolic, diastolic and mean arterial pressure: measured every hour through invasive and noninvasive measurements. The average value of each 6 hour interval was adopted for comparison between the groups;

- the mean value of the heart rate recorded continuously during every 6 hours period;

- maintenance fluids volume (nutrition, IV fluids maintenance, and medications) expressed in $\mathrm{mL} / \mathrm{kg} /$ day;

- volume of extra IV fluids (colloids and crystalloids) administered every 24 hours (expressed in $\mathrm{mL} / \mathrm{kg} /$ day);

- urine output: checked every 6 hours (expressed as $\mathrm{mL} / \mathrm{kg} /$ hour); 
- furosemide administration (expressed as $\mathrm{mg} / \mathrm{kg} /$ day);

- the solutions were infused independently of additional vasoactive drug administrations, which could be increased or decreased along the study period;

- to compare the two groups we used the vasopressor score: ${ }^{14,15}$ [dopamine + dobutamine + (epinephrine X 100) + (norepinephrine X 100) + (milrinone X 10)], all drugs expressed as $\mathrm{mcg} / \mathrm{kg} / \mathrm{min}$. The score value was always evaluated at the same time (4 pm), not considering the additional solution infusion (NE or placebo), since this information was just available at the end of the study;

- sedation: the total amount of drugs administered during 24 hours (continuous infusion plus bolus dose) was measured. The opioids were expressed as morphine equivalents $(10 \mathrm{mg}$ of morphine sulphate $=0.15$ $\mathrm{mg}$ of fentanyl citrate) and the benzodiazepines in diazepam equivalents (10 $\mathrm{mg}$ diazepam $=5 \mathrm{mg} \mathrm{mi}-$ dazolam). The total amount administered per day was expressed in $\mathrm{mg} / \mathrm{kg} /$ day. In addition to the above variables, the IV solution infusion oscillation was also registered.

In this pilot study, the primary outcomes were: hemodynamic response in systolic, diastolic and mean arterial blood arterial pressure, as well as delta mean arterial pressure ( $\triangle \mathrm{MAP}$ ), defined as the difference between the MAP of the specific day minus the MAP on baseline (before starting the drug infusion) and the daily urine output.
The data were collected daily and stored in a Microsoft Excel 2003 spreadsheet. At the end of data collection, the data were exported to a SPSS 11.0 (Statistical Package for the Social Sciences), for statistical analysis.

The sample size was calculated at a $20 \%$ change in urine output (assuming a baseline of $2 \pm 1.5 \mathrm{~mL} / \mathrm{kg} / \mathrm{hr}$ ), with an alpha error of $5 \%$ and power of $80 \%$, obtaining a magnitude effect of 0.7 . The number of patients required in each group was 20.

Data are presented as means \pm standard deviations (SD) or medians with interquartile ranges (IQR). Groups were compared using the Student $t$ test or the Mann-Whitney U test as well as the Chi Square test (or Fisher Exact test) for categorical variables. The multiple comparisons were done using Anova for repeated measures (asymmetrical variables were transformed in log rank variables). The daily comparison between the two groups was performed through the Student $t$ test of the area under the curve (AUC).

\section{Results}

40 consecutive patients were included in the study over a period of 12 months. The two groups (20 patients each) did not differ in respect to the demographic characteristics and PRISM score (Table 1). There were 5 patients with sepsis $(25 \%), 4$ in the NE-group and 1 in the placebo group. Acute viral bronchiolitis and severe acute asthma were the main diagnoses in both groups. The length of MV, the early and late PICU mortality did not show any difference between the two groups.

\section{TABLE 1 Characteristics of patients allocated to the norepinephrine and placebo groups}

\begin{tabular}{|c|c|c|c|c|}
\hline & $\begin{array}{l}\text { All children } \\
(n=40)\end{array}$ & $\begin{array}{l}\text { Norepinephrine } \\
(\mathrm{n}=20)\end{array}$ & $\begin{array}{l}\text { Placebo } \\
(n=20)\end{array}$ & $P$ \\
\hline Age (month) & $3.5(1-111)$ & $3(1-70)$ & $6(2-111)$ & 0.100 \\
\hline Weight (kg) & $6.45(3.1-36)$ & $5.6(3.1-20)$ & $7.05(3.9-36)$ & 0.076 \\
\hline Male gender, n (\%) & $27(67.5)$ & $16(80)$ & $11(55)$ & 0.177 \\
\hline PRISM II score & $9(4-27)$ & $10(4-23)$ & $9(4-27)$ & 0.461 \\
\hline Length of PICU stay (days) & $14(5-107)$ & $14(7-107)$ & $13.5(5-28)$ & 0.489 \\
\hline Length of MV (days) & $9(4-22)$ & $9(4-21)$ & $9.5(4-22)$ & 0.946 \\
\hline \multicolumn{5}{|l|}{ Admitted from } \\
\hline Emergency department & 15 & 10 & 5 & \multirow[t]{2}{*}{0.102} \\
\hline Pediatric/surgical ward & 25 & 10 & 15 & \\
\hline \multicolumn{5}{|l|}{ Main reason for MV } \\
\hline Sepsis & 5 & 4 & 1 & \multirow[t]{4}{*}{0.319} \\
\hline AVB/asthma & 25 & 13 & 12 & \\
\hline Pneumonia & 6 & 2 & 4 & \\
\hline Other & 4 & 1 & 3 & \\
\hline Extubation failure, n (\%) & $4(10 \%)$ & $3(15 \%)$ & $1(5 \%)$ & 0.605 \\
\hline Early PICU mortality, n (\%) & $2(5 \%)$ & $1(5 \%)$ & $1(5 \%)$ & 1.000 \\
\hline Late PICU mortality, n (\%) & $4(10 \%)$ & $1(5 \%)$ & $3(15 \%)$ & 0.605 \\
\hline
\end{tabular}


No differences were observed in baseline characteristics between the two groups in regard to heart rate, arterial blood pressure, fluid maintenance, vasopressor infusion and fluid bolus (Table 2). The average dose of diazepam/morphine for both groups was similar, as well as the number of children receiving IV Beta2 agonists infusion $(\mathrm{p}=0.15)$.

The infusion rates of placebo and NE-solution administered during the intervention period ( 3 days) were $1.43 \pm 0.67$ $\mathrm{mL} / \mathrm{kg} / \mathrm{hr}$ and $1.43 \pm 0.75 \mathrm{~mL} / \mathrm{kg} / \mathrm{hr}$, respectively $(\mathrm{p}=0.813)$, corresponding to a norepinephrine infusion of $0.14 \pm 0.75$ $\mathrm{mcg} / \mathrm{kg} / \mathrm{min}$ in the NE-group. The mean systolic and diastolic arterial blood pressures in both groups did not change significantly over the study period (Figure 1A). However, the delta mean arterial blood pressure (difference in the mean arterial pressure between a specific day compared to the first day) was maintained significantly positive in the NE group (Figure 1B) during all the study period $(\mathrm{p}=0.043)$, returning to the baseline when norepinephrine was withdrawn (4 $4^{\text {th }}$ day); the delta mean arterial pressure showed a negative oscillation in the placebo group during all the study period.

\section{TABLE 2 Baseline characteristics of the population}

\begin{tabular}{|c|c|c|c|c|}
\hline & $\begin{array}{l}\text { All children } \\
(\mathrm{n}=40)\end{array}$ & $\begin{array}{l}\text { Norepinephrine } \\
(n=20)\end{array}$ & \begin{tabular}{|l|} 
Placebo \\
$(\mathrm{n}=20)$
\end{tabular} & $\mathrm{p}$ \\
\hline $\mathrm{HR}(\mathrm{bpm})$ & $148.8 \pm 22.2$ & $151.8 \pm 16.7$ & $145.7 \pm 26.7$ & $0.397^{+}$ \\
\hline $\mathrm{RR}(\mathrm{bpm})$ & $36.1 \pm 12.8$ & $35.4 \pm 10.7$ & $36.7 \pm 14.8$ & $0.752^{+}$ \\
\hline Systolic blood pressure $(\mathrm{mmHg})$ & $104.5 \pm 10.7$ & $102 \pm 11.4$ & $107.1 \pm 9.7$ & $0.139^{+}$ \\
\hline Diastolic blood pressure $(\mathrm{mmHg})$ & $52.3 \pm 8.2$ & $52.4 \pm 8.1$ & $52.2 \pm 8.6$ & $0.955^{+}$ \\
\hline Mean arterial pressure $(\mathrm{mmHg})$ & $73.2 \pm 9.4$ & $71.3 \pm 9.2$ & $75.1 \pm 9.4$ & $0.200^{+}$ \\
\hline Urine output (mL/kg/h) & $3.9 \pm 2.6$ & $4.3 \pm 2.9$ & $3.5 \pm 2.2$ & $0.316^{+}$ \\
\hline Maintenance fluid $(\mathrm{mL} / \mathrm{kg} / \mathrm{d})$ & $101 \pm 19.3$ & $106.2 \pm 19.7$ & $95.7 \pm 18$ & $0.086^{+}$ \\
\hline \multicolumn{5}{|l|}{ IV Fluid bolus $(\mathrm{mL} / \mathrm{kg} / \mathrm{d})$} \\
\hline $\mathrm{N}(\%)$ & $34(85 \%)$ & $19(95 \%)$ & $15(75 \%)$ & \\
\hline Median & $21(0-202.4)$ & $29.1(0-202.4)$ & $16.0(0-115.4)$ & $0.291^{*}$ \\
\hline \multicolumn{5}{|l|}{ Vasopressor score } \\
\hline Median & $5(0-55)$ & $5(0-55)$ & $0(0-25)$ & $0.16^{*}$ \\
\hline \multicolumn{5}{|l|}{ Sedatives } \\
\hline Morphine $(\mathrm{mg} / \mathrm{kg} / \mathrm{d})$ & $0.48(0-1.56)$ & $0.51(0-1.56)$ & $0.44(0-1.44)$ & $0.725^{*}$ \\
\hline Diazepam $(\mathrm{mg} / \mathrm{kg} / \mathrm{d})$ & $6.3(1.1-19.6)$ & $6.5(2-17.2)$ & $4.4(1.1-19.6)$ & $0.57^{*}$ \\
\hline IV Beta2 agonist $\mathrm{n}(\%)$ & $11(27.5 \%)$ & $3(15 \%)$ & $8(40 \%)$ & $0.156^{\#}$ \\
\hline \multicolumn{5}{|l|}{ Blood acid base } \\
\hline $\mathrm{pH}$ & $7.33 \pm 0.16$ & $7.32 \pm 0.17$ & $7.33 \pm 0.16$ & $0.885^{+}$ \\
\hline $\mathrm{HCO}_{3}{ }^{-}$ & $19.4 \pm 5.3$ & $17.9 \pm 4.8$ & $20.9 \pm 5.4$ & $0.067^{+}$ \\
\hline Hemoglobin & $9.9 \pm 1.9$ & $9.8 \pm 2.2$ & $9.9 \pm 1.7$ & $0.981^{+}$ \\
\hline Sodium & $136.4 \pm 4.7$ & $136.1 \pm 5.4$ & $136.6 \pm 4.1$ & $0.719^{+}$ \\
\hline Potassium & $4.4 \pm 0.7$ & $4.4 \pm 0.8$ & $4.4 \pm 0.7$ & $0.933^{+}$ \\
\hline
\end{tabular}

+ Values with normal distribution were expressed through mean+ SD and compared using the Student $\mathrm{t}$ test;

* Values with asymmetrical distribution were expressed through median (range) and compare using the $U$ Mann-Whitney test

\# Percentage values were compared using the Chi Square test or the Exact Fischer test
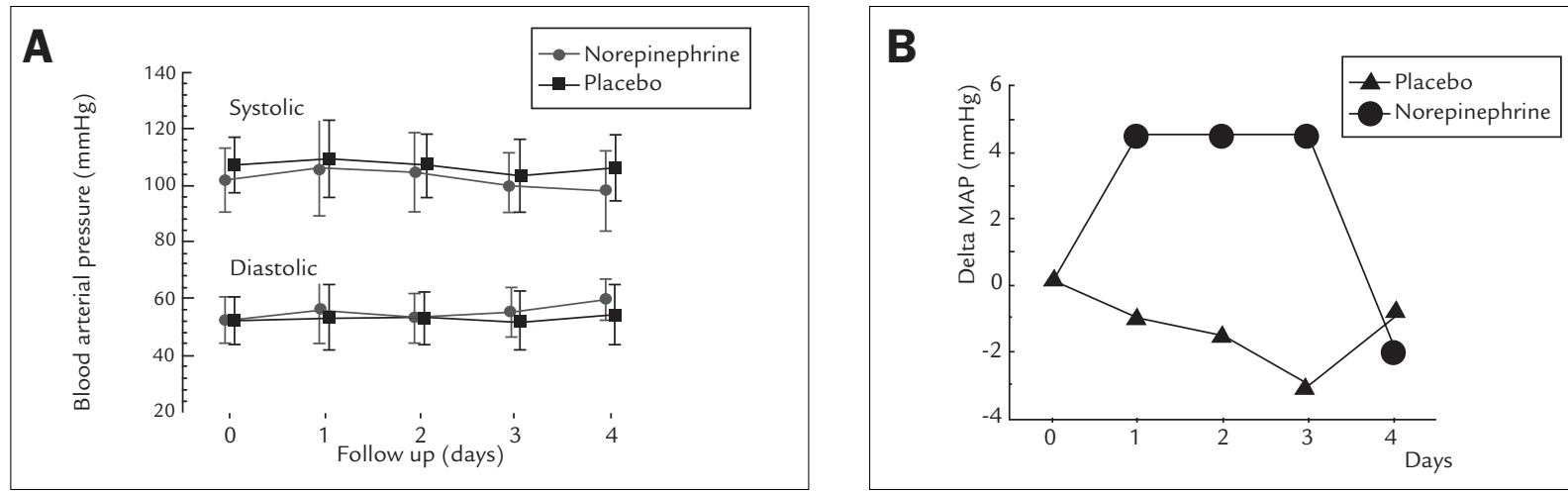

FIGURE 1 A Daily arterial blood pressure measurements observed during the study period. Systolic values are drawn in the top of the figure and diastolic values in the bottom. Values were expressed in $\mathrm{mmHg}$ (mean $\underline{+} \mathrm{sd}$ ). B Delta mean arterial blood pressure (difference between mean arterial pressure in a specific day compared to the first day) was maintained significantly positive in the NE group (Anova $=0.043$ ), returning to the basal level when norepinephrine infusion was withdrawn $\left(4^{\text {th }}\right.$ day). In the placebo group this gradient was negative over all time of the study (ANOVA= 0.12). Values were expressed in $\mathrm{mmHg}$ (means $\pm \mathrm{sd}$ ). 
Heart rate, vasopressor score, daily fluid maintenance, amount of volume expansion, and dosage of diazepam/ morphine infused over the study period did not differ between the two groups (Table 3). However, urine output was significantly higher in the NE-group during the period study $(\mathrm{p}=0.016)$ with no difference in the amount of diuretics (furosemide) received between the two groups $(\mathrm{p}=0.61)$.

The study was interrupted in four cases, 3 because of early tracheal extubation and in one patient (NE-group) due to tachycardia $(200 \mathrm{bpm})$. This patient had septic shock with a vasopressor score of 65 [(epinephrine $=0.5$ versus 100$)+$ dobutamine $=10+($ Milrinone $=0.5$ versus $10)]$. In this case, even though tachycardia was not attributed to the norepinephrine or placebo infusion, the medical staff and the authors agreed to cease the infusion and withdraw the patient from the study.

\section{Discussion}

In this randomized, double-blinded, pilot study we observed that the early administration of low dose norepinephrine in children undergoing MV, requiring sedative and analgesic infusions, increased significantly the urine output associated with an increment in the mean arterial pressure gradient. The delta MAP was maintained positively during all the NE-infusion period, and negatively in the placebo group.

Opioid and benzodiazepine drugs, even at therapeutic dosages, increase cutaneous blood flow secondary to vasodilatation and alterations of the capillary flow. ${ }^{1,2,4,5,7}$ This microvascular derangement can induce increased endothelial permeability, heterogeneity of blood flow and tissue hypoxia, which will lead to fluid retention, edema and oliguria - frequently observed in children requiring MV and sedative and analgesic infusions. ${ }^{1,2,10,16}$ In this re-

\section{TABLE 3 Daily fluid maintenance, volume infusion and vasopressor score in the two groups}

\begin{tabular}{|c|c|c|c|c|c|c|}
\hline & Basal & 1 & 2 & 3 & 4 & $\mathrm{p}$ \\
\hline \multicolumn{7}{|c|}{ Heart rate (bpm) } \\
\hline NE-group & $152 \pm 17$ & $146 \pm 22$ & $143 \pm 18$ & $141 \pm 17$ & $136 \pm 19$ & *0.421 \\
\hline Placebo-group & $146 \pm 27$ & $142 \pm 29$ & $136 \pm 29$ & $137 \pm 27$ & $134 \pm 24$ & \\
\hline \multicolumn{7}{|c|}{ Fluid (mL/kg/day) } \\
\hline NE-group & $106 \pm 20$ & $106 \pm 19$ & $112 \pm 28$ & $115 \pm 24$ & $120 \pm 23$ & *0.444 \\
\hline Placebo-group & $96 \pm 18$ & $96 \pm 23$ & $101 \pm 26$ & $97 \pm 21$ & $112 \pm 30$ & \\
\hline \multicolumn{7}{|c|}{ IV Bolus (mL/kg/day) } \\
\hline NE-group & $29(0-202)$ & $10(0-66)$ & $10(0-51)$ & $0(0-24)$ & $0(0-38)$ & *0.699 \\
\hline Placebo-group & $16(0-115)$ & $7.5(0-63)$ & $0(0-42)$ & $0(0-115)$ & $9(0-115)$ & \\
\hline \multicolumn{7}{|c|}{ Vasopressor score ${ }^{a}$} \\
\hline NE-group & $5(5-55)$ & $6.25(0-73)$ & $10(0-51)$ & $9.9(0-45)$ & $8.9(0-115)$ & *0.888 \\
\hline Placebo-group & $0(0-25)$ & $8.75(0-60)$ & $11(0-75)$ & $8.75(0-135)$ & $8.75(0-115)$ & \\
\hline \multicolumn{7}{|c|}{ Urine output (mL/kg/hr) } \\
\hline NE-group & $4.3 \pm 2.9$ & $4.7 \pm 1.7$ & $5.1 \pm 1.7$ & $4.9 \pm 1.5$ & $4.5 \pm 1.2$ & *0.016 \\
\hline Placebo-group & $3.5 \pm 2.2$ & $3.9 \pm 1.6$ & $3.8 \pm 1.0$ & $4.1 \pm 1.5$ & $4.5 \pm 1.5$ & \\
\hline \multicolumn{7}{|c|}{ Furosemide (mg/kg/day) } \\
\hline NE-group & $0(0-2.5)$ & $0.25(0-2.3)$ & $1(0-4.2)$ & $0.5(0-4.2)$ & $0.7(0-4.5)$ & *0.616 \\
\hline Placebo-group & $0(0-2.6)$ & $1(0-3.2)$ & $1.1(0-6.0)$ & $0.9(0-4.3)$ & $0.5(0-4.2)$ & \\
\hline \multicolumn{7}{|c|}{ Diazepam (mg/kg/day) } \\
\hline NE-group & $6.5 \pm 3.6$ & $7.3 \pm 2.6$ & $7.1 \pm 3.6$ & $6.1 \pm 3.5$ & $4.9 \pm 3.2$ & *0.091 \\
\hline Placebo-group & $6.9 \pm 5.9$ & $8.9 \pm 4.0$ & $8.9 \pm 4.2$ & $9 \pm 4.5$ & $7.1 \pm 4.5$ & \\
\hline \multicolumn{7}{|c|}{ Morphine (mg/kg/day) } \\
\hline NE-group & $0.5 \pm 0.4$ & $0.8 \pm 0.4$ & $0.8 \pm 0.5$ & $0.7 \pm 0.4$ & $0.6 \pm 0.4$ & *0.188 \\
\hline Placebo-group & $0.5 \pm 0.4$ & $1 \pm 0.6$ & $1.1 \pm 0.8$ & $1 \pm 0.8$ & $0.8 \pm 1$ & \\
\hline
\end{tabular}

NE-group $=$ children receiving norepinephrine infusion; Vasopressor Score $=[$ dopamine + dobutamine $+($ epinephrine X 100) $+($ norepinephrine X 100 $)+($ milrinone X 10) $]$. a-The vasopressor score was calculated without considering the infused solution (placebo or norepinephrine). It was used to compare impact of both solutions in the hemodynamic response. The continuous variables were expressed as mean and SD, being compared through the Anova one way and by the area under the curve (Auc*). The asymmetrical variables were expressed as median with the respective range, being through the Anova log rank and by the area under the curve (Auc*) 
gard, it has been demonstrated that positive fluid balance is strongly associated with poor prognosis in children submitted to mechanical ventilation. ${ }^{17,18}$

Tissue perfusion depends on the microcirculatory perfusion pressure (the net result of pre-capillary inflow pressure minus venular outflow pressure) and divided by the local vascular resistance. ${ }^{8,9}$ Small arterioles are the principal site of active diameter changes (resistance vessels) to achieve regulation of capillary blood flow. ${ }^{10}$ Vasoplegia induced by sedative and analgesic drugs decreases the flow regulatory capacity of the arterioles; consequently, the mean capillary pressure is much closer to the venous pressure than to the arterial pressure, which is crucial for the maintenance of tissue perfusion. ${ }^{10,17}$

Considering the effects of sedative and analgesic drugs on the capillary flow, the early administration of a vasopressor agent could restore the tissue pressure perfusion and maintain cell metabolism.

We evaluated the vasopressin infusion in this scenario (children requiring mechanical ventilation and sedative and analgesic infusions) and observed that early vasopressin infusion (compared to placebo) induced an acute increment in MAP $(72.4 \pm 12$. vs. $62.6 \pm 4.6 \mathrm{mmHg}$; $\mathrm{p}=0.02)$ but did not prevent the need for other vasoactive agents (being required in $82 \%$ of children in the vasopressin group). Use of vasopressin, however, was associated with higher incidence of hyponatremia (66\% in the vasopressin group versus only $8 \%$ ) in the saline group. ${ }^{19}$ Considering the side effects observed with early vasopressin infusion and the scarce data on norepinephrine infusion in the pediatric population, we planned and conducted this pilot study.

Compared to other vasoactive drugs, norepinephrine has been associated with lower incidence of cardiac arrhythmias, increased global oxygen delivery, and enhanced cutaneous microvasculature flow and tissue oxygenation. ${ }^{10,11,12,16,18,20,21,22}$ Norepinephrine is the most common vasopressor drug used in septic shock to maintain mean arterial pressure (MAP). ${ }^{10,11,12,16,20-24}$ In the presence of microvascular derangement, volume resuscitation alone is not sufficient to restore and maintain mean arterial pressure despite improvement in the aortic blood flow. Use of early norepinephrine infusion, however, can restore mean arterial pressure. ${ }^{25}$ Besides a significant effect on the arterial pressure, norepinephrine also increases the venous blood flow. ${ }^{10,18,24-27}$

In this study, early norepinephrine infusion at a low dosage $(0.15 \mathrm{mcg} / \mathrm{kg} / \mathrm{min})$ maintained the MAP in the normal range, but significantly higher than the baseline MAP. When the infusion was stopped, a significant decrease in MAP was observed. Considering that there were no differences between the two groups related to the volume infusion and diuretic administration, we could infer that the higher urine output in the norepinephrine group would be attributed to a positive effect on renal perfusion.

Historically, norepinephrine (in high doses) was associated with excessive vasoconstriction and deterioration of renal perfusion. ${ }^{23,28,29}$ However, several studies (including the present one) suggest that norepinephrine in lower doses, infused in vasoplegic patients, increases the renal perfusion pressure promoting recovery of the urinary output and improving the creatinine clearance. $8,9,11,12,23,25,30$ In a selected group of neonates with septic shock refractory to dopamine/dobutamine, norepinephrine infusion reduced the lactate levels and increased $70 \%$ in the urine output. ${ }^{31}$

We are aware that our study has some limitations and several aspects could be questioned, such as:

- why compare the two groups through the delta MAP instead using the MAP means. Sometimes it may be difficult to demonstrate statistical difference when comparing means with great dispersion (high standard deviation magnitude) and involving small groups. In such circumstances, it may be easier to compare the delta difference (oscillation) observed in both groups regarding the onset of the study (baseline);

- patients receiving Milrinone (drug with inotrope and vasodilator action) were not excluded. In our study there were three patients receiving milrinone infusion (one in the NE group and two in the placebo group). However, considering that the vasopressor score includes milrinone, we decided that it would be appropriated and closer to the real scenario not to exclude these patients;

- the study was conducted in just one center with a small and heterogeneous population;

- it would be advisable to use as a primary outcome more robust markers, such as the survival rate, the duration of MV or the length of hospital stay. Clearly, increasing MAP and urine output do not necessarily reflect improvement on tissue perfusion and may not impact the major outcomes (mortality rate or length of mechanical ventilation). However, some studies involving pediatric population demonstrated that the mortality rate as well as the duration of MV could be affected by these variables; ${ }^{18,32,33}$ 
- considering the small number or patients allocated to each group we cannot advise the safety of this infusion. We found only one patient with tachycardia, and this patient was receiving other vasoactive drug infusions that are more frequently related to tachyarrhythmia than norepinephrine. . $02,21^{20,2}$

\section{Conclusion}

In conclusion, our study suggests that early norepinephrine infusion in children submitted to MV requiring sedative and analgesic infusion can increase MAP and urine output by, likely, restoring the vasomotor tone. Studies involving larger populations are needed to define the optimal dose and timing for initiation norepinephrine infusion, the subgroup of pediatric patients that would benefit from this therapy, and to evaluate its effect on clinical outcomes (mortality and length of PICU stay).

The study was partly supported by the 'Brazilian Research Council' (CNPq). The study was registered in the 'Clinical Trials.Gov' (NCT ‘00894621).

\section{RESUMO}

Infusão de noradrenalina aumenta o débito urinário de crianças recebendo drogas sedoanalgésicas

Objetivo: avaliar os efeitos da infusão de noradrenalina (NA) em crianças submetidas a ventilação mecânica (VM) requerendo infusão contínua de sedoanalgesia.

Métodos: estudo duplo cego, randomizado e placebo controlado envolvendo crianças de 1 mês a 12 anos, admitidas em uma UTI pediátrica brasileira com a expectativa de necessidade de VM e sedoanalgesia por, no mínimo, 5 dias. As crianças foram randomizadas a receber infusão de NA $(0,15 \mathrm{mcg} / \mathrm{kg} / \mathrm{min})$ ou solução salina, iniciadas nas primeiras 24 horas de VM e mantidas por 72 horas. Comparamos as variáveis hemodinâmicas, oferta hídrica, função renal e débito urinário entre os dois grupos.

Resultados: 40 crianças foram alocadas aos grupos NA e placebo, sem diferenças nas características basais, achados laboratoriais, escore PRISM II, tempo de VM ou mortalidade. A infusão média de NA foi $0,143 \mathrm{mcg} / \mathrm{kg} / \mathrm{min}$. O grupo NA apresentou maior débito urinário $(\mathrm{p}=0,016)$ e aumento constante da pressão arterial média quando comparado aos níveis basais $(\mathrm{p}=0,043)$. Não se observou diferenças nas demais variáveis hemodinâmicas, reposição hídrica ou no uso de furosemida.

Conclusão: infusão precoce de NA em crianças submetidas a VM em uso sedoanalgesia promove aumento na pressão arterial média e aumento da diurese. Esses efeitos são atribuídos à reversão da vasoplegia induzida pelas drogas sedativas e analgésicas.

Unitermos: vasopressor; vasoplegia; choque; sedativo; débito urinário.

\section{References}

1. Devlin JW, Mallow-Corbett S, Riker R. Adverse events associated with the use of analgesics, sedative and antipsycotics in the intensive care unit. Crit Care Med 2010; 38(Suppl.):S231-S243.

2. Devlin JW. The pharmacology of oversedation in mechanically ventilated adults. Curr Opin Crit Care 2008; 14:403-407

3. Sfoggia A, Fontela P, Piva J, da Silva F, Sober RB, Noer RB et al. Sedation and analgesia in children submitted to mechanical ventilation could be overestimated? J Pediatr (Rio J.) 2003; 79:343-8

4. Playfor S, Jenkins I, Boyles C, Choonara I, Davies G, Haywood T et al. Consensus guidelines on sedation and analgesia in critically ill children. Int Care Med 2006; 32:1125-36

5. Tobias JD. Tolerance, withdrawal and physical dependency after long-term sedation and analgesia of children in the pediatric intensive care unit. Crit Care Med 2000; 28:2122-32.

6. Jacobi J, Fraser GL, Coursin DB, Riker RR, Fontaine D, Wittbrodt ET et al. Clinical practice guidelines for the sustained use of sedatives and analgesics in the critically ill adult. Crit Care Med 2002; 30:119-41.

7. Richman PS, Baram D, Varela M, Glass PS. Sedation during mechanical ventilation: a trial of benzodiazepine and opiate in combination. Crit Care 2006; 34:1395-401.

8. Brierley J, Carcillo JA, Choong K, Cornell T, Decaen A, Deymann A et al 2007 American College of Critical Care Medicine clinical practice parameters for hemodynamic support of pediatric and neonatal septic shock. Crit Care Med 2009; 37:1-23.

9. Carcillo J, Han K, Lin J, Orr R. Goal-directed management of pediatric shock in the emergency department. Clin Pediatr Emerg Med 2007; 8:165-75.

10. Boerma EC, Ince C. The role of vasoactive agents in the ressuscitation of microvasculature perfusion and tissue oxygenation in crtically ill patients. Int Care Med 2010; 36:2004-18.

11. Bourgoin A, Leone M, Delmas A, Garnier F, Albanèse J, Martin C. Increasing mean arterial pressure in patients with septic shock: effects on oxygenation variables and renal function. Crit Care Med 2005; 33:780-6.

12. Redfors B, Bragadottir G, Sellgren J, Swärd K, Ricksten SE. Effects of norepinephrine on renal perfusion and oxygantion in vasodilatory shock and acute kidney injury. Int Care Med 2011; 37:60-7.

13. Dellinger RP, Carlet JM, Masur H, Gerlach H, Calandra T, Cohen J et al. Surviving Sepsis Campaign guidelines for management of severe sepsis and septic shock. Int Care Med 2004; 30:536-55.

14. Wernovsky G, Wypij D, Jonas RA, Mayer JE Jr, Hanley FL, Hickey PR et al. Postoperative course and hemodynamic profile after the arterial with operation in neonates and infants. A comparison of low-flow cardiopulmonary bypass and circulatory arrest. Circulation 1995; 92:2226-35.

15. Rosenzweig E, Starc T, Chen J, Cullinane S, Timchak D, Gersony W. Intravenous arginine-vasopressin in children with vasodilatory shock after cardiac surgery. Circulation 1999; 100:II-182-6.

16. Jhani S, Stirling S, Patel N, Hinds C, Pearse R. The effect of increasing doses of norepinphrine on tissue oxygenation and microvascular flow in patients with septic shock. Crit Care Med 2009; 37:1961-6.

17. Selewski D, Cornell T, Lombel R, Blatt NB, Han YY, Mottes T et al. Weightbased determination of fluid overload status and mortality in pediatric intensive care unit patients requiring continuous renal replacement therapy. Int Care Med 2011; 37:1166-73.

18. Flori HR, Church G, Liu KD, Gildengorin G, Matthay MA. Positive fluid balance is associated with higher mortality and prolonged mechanical ventilation in pediatric patients with acute lung injury. Crit Care Res Pract 2011; 2011:854142.

19. Baldasso E, Garcia PC, Piva J, Branco R, Tasker R. Pilot safety study of lowdose vasopressin in non-septic critically ill children. Int Care Med 2009; 35:355-9. 
20. De Backer D, Binston P, Devriendt J, Madl C, Chochrad D, Aldecoa C et al. Comparison of dopamine and norepinephrine in the treatment of shcok. N Engl J Med 2010; 362:779-89.

21. Myburgh J, Higgins A, Jovanovska A, Lipman J, Ramakrishnan N, Santamaria $\mathrm{J}$ et al. A comparison of epinephrine and norepinephrine in critically ill patients. Int Care Med 2008; 34:2226-34

22. Leone M, Martin C. Vasopressor use in septic shock: an update. Curr Opin Anaesthesiol 2008; 21:141-7.

23. Bellomo R, Giantomasso DD. Noradrenaline and the kidney: friends or foes? Crit Care 2001; 5:294-8.

24. Morimatsu H, Singh K, Uchino S, Bellomo R, Hart G. Early and exclusive use of norepinephrine in septic shock. Resuscitation 2004; 62:249-54.

25. Sennoun N, Montemont C, Gibot S, Lacolley P, Levy B. Comparative effects of early versus delayed use of norepinephrine in resuscitated endotoxic shock. Crit Care Med 2007; 35:1736-40.

26. Beale R, Hollenberg S, Vincent J, Parrillo J. Vasopressor and inotropic support in septic shock: an evidence-based review. Crit Care Med 2004; 32(Supp):S455-65.

27. Overgaard C, Dzavík V. Inotropes and vasopressors: review of physiology and clinical use in cardiovascular disease. Circulation 2008; 118:1047-56.
28. Mills L, Moyer J, Handley C. Effects of various sympathomimetic drugs on renal hemodynamics in normotensive and hypotensive dogs. Am J Physiol 1960; 198:1279-85.

29. Cronin R, Erickson A, Torrente A, McDonald KM, Schrier RW. Norepinephrineinduced acute renal failure: a reversible ischemic model of acute renal failure. Kidney Int 1978; 14:187-90.

30. Albanese J, Leone M, Garnier F. Renal effects of norepinephrine in septic and nonseptic patients. Chest 2004; 126:534-9

31. Tourneux P, Rakza T, Abazine A, Krim G, Storme L. Noradrenaline for management of septic shock refractory to fluid loading and dopamine or dobutamine in full-term newborn infants. Acta Paediatr 2008; 97:177-80.

32. Arikan AA, Zappitelli M, Godstein SL, Naipaul A, Jefferson LS, Loftis LL. Fluid overload is associated with impaired oxygenation morbidity in critically ill children. Pediatr Crit Care Med 2011; 13:253-8.

33. Willson D, Thomas JN, Tamburro R, Truemper E, Truwit J, Conaway M et al. The relationship of fluid administration to outcome in the pediatric calfactant in acute respiratory distress syndrome trial. Pediatr Crit Care Med 2013; 14:666-72. 